\title{
Research on Master of Engineering Management in China
}

\author{
Dan Erli \\ School of Economics and Management, North China \\ Electric Power University \\ Beijing, China \\ erlidan@ncepu.edu.cn
}

\author{
Tan Xingxing \\ School of Economics and Management, North China \\ Electric Power University, \\ Beijing, China \\ 761247978@qq.com
}

\author{
Guo Yiwei \\ School of Economics and Management, North China Electric Power University \\ Beijing, China \\ guoyiwei@ncepu.edu.cn
}

\begin{abstract}
This paper analysed the current situation of the degree of full-time study and part-time study, and compares the number of institutions that establish the master's degree of engineering management, duration, curriculums, duration of practice, the process and the quality of the entire thesis writing. This study is based on a survey, in which we compiled master enrollment brochures, catalogs and other related information of 99 institutions in 2017. The results show that there are 40 colleges or universities enrolling students of both full-time and part-time. But the training programs vary among institutions. For example, though minimum duration of full-time and part-time is both two years, but maximum duration in full-time (6 years) is one year more than full-time (5 years).In addition, the duration of practice paper requirements, quality management and other aspects also showed a different pattern. These aspects are needed to be paid close attention to and explored.
\end{abstract}

Keywords-Master of engineering management; training mode; curriculum setting; practice time; thesis quality management

\section{INTRODUCTION}

Engineering management is decision-making, planning, organizing, directing, coordinating and controlling for engineering practice. It includes the technical and economic demonstration of the decision-making of major construction projects and the management in implementation, and the research and management of the major layout and development strategy of industry, engineering and science and technology. With the large scale and complicated decision-making process of modern engineering, involving a wide range of technologies, great organization structure, long duration and many participants, engineering management is becoming more and more important, and it also forces engineering managers to improve their own level to be competent for engineering management positions.

"In order to adapt to the development of modern engineering in our country, the urgent need for engineering management personnel, improve the training system of engineering management talents, innovative management personnel on training mode, improve the quality of human resources in Engineering Management", Proposed by the Chinese Academy of engineering, Tsinghua University commissioned the subject of proof, in 2010 approved the new master of Engineering Management Master degree [1]. Setting master's degree in engineering management, on the one hand, conforms to the actual needs of engineering enterprises, reduces the cost of training talents for engineering management and on the other hand meets the needs of career planning of practitioners in engineering field. In 2010 alone, 77 universities received degrees in Engineering Management, and growth slowed in the following years [2]. By 2017, a total of 99 institutions were authorized.

\section{THE PROJECT MANAGEMENT MASTER (MEM) ENROLLMENT TARGETS, TRAINING OBJECTIVES AND TRAINING MODEL}

Master of Engineering Management has great difference compare with master of Engineering in project management [3] Master of Engineering in Industrial Engineering and master of Business Administration (MBA) levels in the training target, and service industries, and it has a wider range of subjects. Compared with the academic master of engineering management, MEM professional degree is required by the professional background [4].

\section{A. Enrollment Target}

The master degree of Engineering Management in China is a professional degree with engineering management background. It mainly aims at training high-level talents facing all kinds of project management needs [5]. The object of education is characterized by obvious business background and practical application

As candidates have job experience requirements, students mainly have several years of engineering work experience of technical personnel or management personnel. All colleges and universities in China for master of Engineering Management admissions requirements are: after graduating from college 3 years or 3 years of work experience; to obtain national recognition of vocational education after graduation, 5 years or 
above 5 years work experience, and to university graduates equivalent force personnel have been; master degree or $\mathrm{PhD}$ degree and 2 years or above 2 years work experience.

\section{B. Train objective}

The degree committee of the State Council and the project management branch of the Steering Committee on management science and engineering of the Ministry of education put forward that the master of engineering management needs to train high-level, complex and applied engineering management professionals [4]. They are learning to master the system management theory (management science, economics, etc.), modern management methods, and specific knowledge engineering (basic knowledge of Civil Engineering Technology) at the same time, but also to have the process management (planning, organization, coordination) and decision-making ability.

\section{Training mode}

There are some differences in teaching time between fulltime and part-time graduate students, but holistic training takes both curriculum learning, practice teaching and Dissertation [5]. Academic dissertation is the core link in the process of graduate education [3]. But the course setting, practice, strength and effect, and the quality management of theses are very important in training.

Different institutions combined with the documents issued by the Academic Degrees Committee of the State Council, in accordance with their own characteristics, formulated training programs, in terms of training years, training methods, graduation (thesis, credit, etc.) requirements have specific requirements.

\section{FINDING}

We conducted a survey about training master of engineering management of domestic 99 authorized institutions, the survey covers the setting of Engineering Management Master degree, educational system, curriculum, practice time requirements, the quality of management and etc.

A. The setting of master's degree in Engineering Management

In 99 institutions, there are 48 full-time Master of engineering management, and 73 non full-time Master of Engineering Management. The number of part-time engineering management masters is $52 \%$ more than that of fulltime institutions. 40 of these institutions also recruit two master of Engineering Management as shown in Table 1.

TABLE I HIGHER EDUCATION INSTITUTES WHICH RECRUIT BOTH FULL-TIME AND PART-TIME PROJECT MANAGEMENT MASTER (MEM)

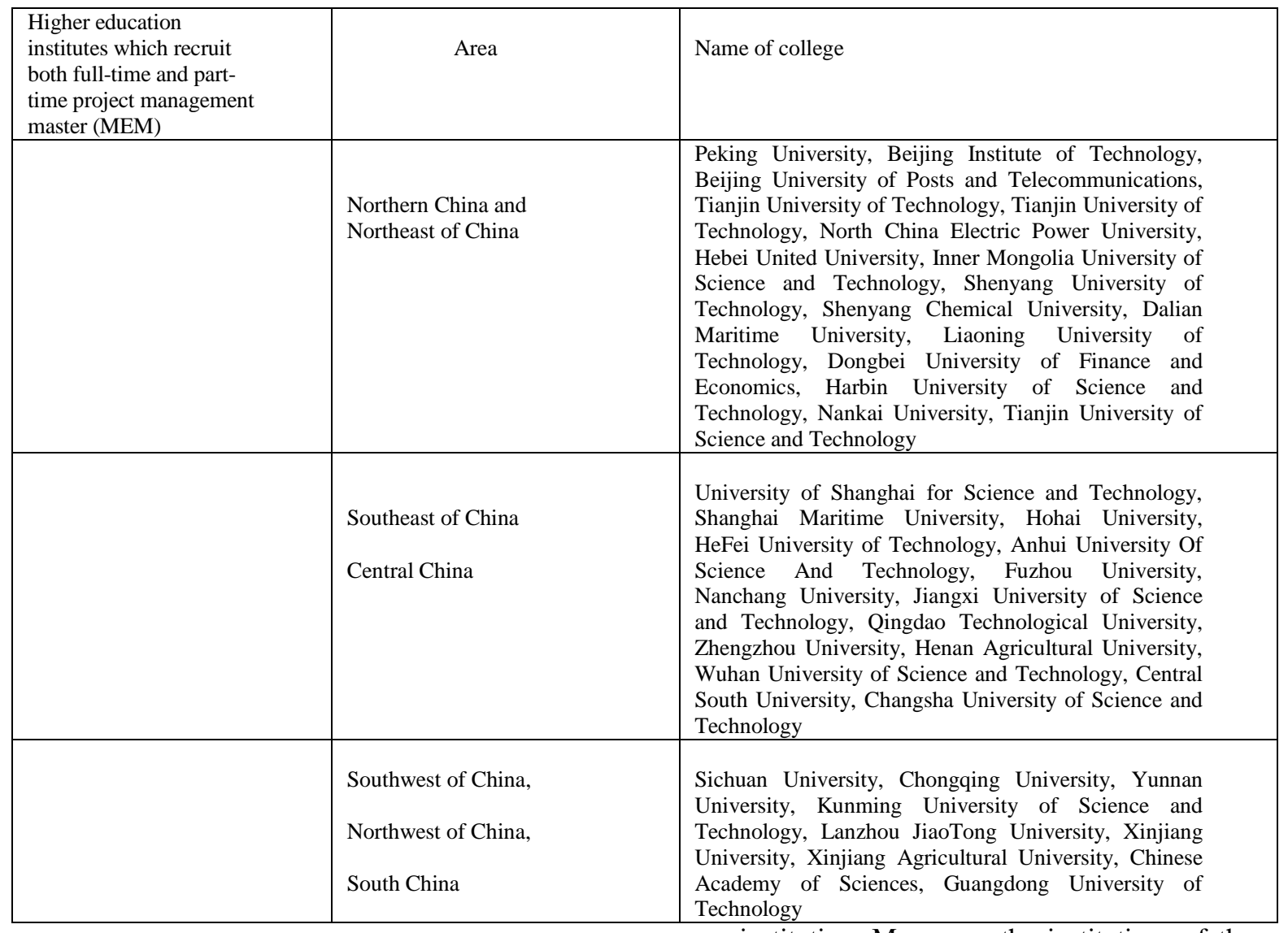

\section{B. Educational system design}

According to the survey statistics, there are differences in the system design of the two types of master of engineering management between full-time and part-time students in the same institution. Moreover, the institutions of the same type require different educational systems. Among them, there are 42 institutions to explain the minimum full-time period. There are three kinds of school system design, which are 2 years, 2.5 years and 3 years respectively. Among them, 19 institutions 
used 2 years as the minimum number of years, is the three choice of the largest number of design. For the maximum age setting, information about 41 institutions shows 4 designs, 2.5 years, 3 years, 4 years, 5 years. There are 16 (the largest number) institutions selected for 4 years, the number of 3,5 is more than 10 . Only 1 institutions chose 2.5 years, as shown in Table 2.

TABLE II THE CHOICE OF MAXIMUM DURATION OF FULL-TIME DEGREE OF INSTITUTIONS

\begin{tabular}{|c|c|c|c|c|}
\hline $\begin{array}{c}\text { The choice of } \\
\begin{array}{c}\text { maximum duration of } \\
\text { full-time degree of } \\
\text { institutions }\end{array}\end{array}$ & 2.5 & 3 & 4 & 5 \\
\cline { 2 - 5 } & 1 & 10 & 16 & 14 \\
\hline Number of institutions & 10 full year (year) \\
\hline
\end{tabular}

Setting up a master's degree in part-time Engineering Management(66), 29 (39.4\%) schools limit their minimum years to 3 years, is the largest in number, Followed by 2 years. 2.5 years of design, compared to the institutions employed, 3 years less than half. There are 67 sets of statistics in the longest duration, more than half (39) of the institutions chose the 5 year as the ceiling for their study years, which took the absolute advantage. Only 1 choose 6 years, choose 3 years, 4 years, each accounted for about $20 \%$. As shown in Table 3.

After statistics on the training period of part-time project management, it is found that there are 25 institutions with a minimum length of 3 years and a maximum length of 5 years. It is the setting of the most frequent training years (as shown in Table 4)

TABLE III DESIGN OF LONGEST YEARS OF MASTER'S DEGREE IN NON- FULL TIME ENGINEERING MANAGEMENT

\begin{tabular}{|l|c|c|c|c|}
\hline $\begin{array}{l}\text { Design of longest years of master's } \\
\text { degree in non- full time } \\
\text { engineering management }\end{array}$ & 3 & 4 & 5 & 6 \\
\hline $\begin{array}{l}\text { Number of higher education } \\
\text { institutions }\end{array}$ & 11 & 16 & 39 & 11 \\
\hline
\end{tabular}

TABLE IV DESIGN OF MASTER'S DEGREE IN NON FULL TIME PROJECT MANAGEMENT

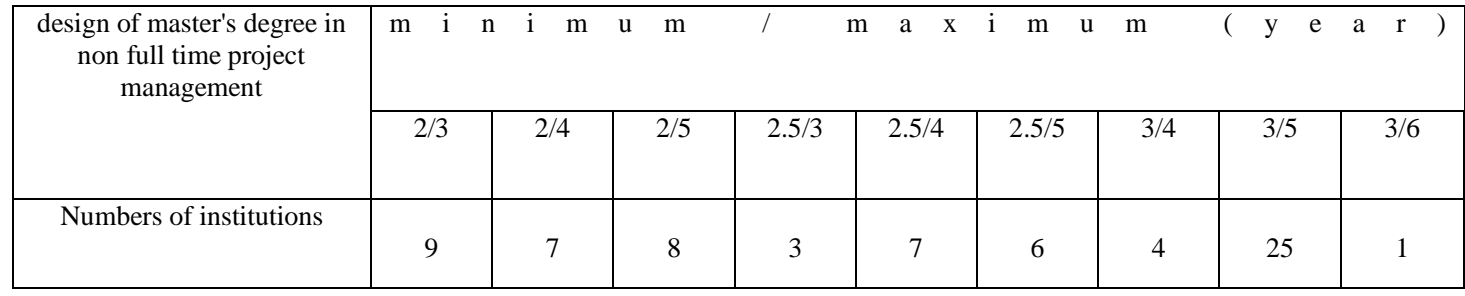

\section{Courses offered}

Each school is unique in its curriculum, with required courses in public basic courses, basic courses in engineering management, majors, and other disciplines, including practical sessions, lectures, and dissertations [2]. Some schools also emphasize the requirements of degree credits and practice credits, For example, 26 institutions, including the Tongji University and the Xi'an Jiao Tong University, have specific requirements to balance different types of courses.

With the encouragement and support of the relevant departments of the state, a number of universities and research institutes have actively carried out joint training in various forms in China [6]. In the joint training of management mechanism, innovation and training mode innovation and other areas have accumulated some experience, and achieved positive results. Such cooperation including the Ministry of education special plan, international cooperation, diversified cooperation mode, to achieve the project partners and mentor, sharing resources, the establishment of collaborative innovation system, build a common platform and combined training of the Postgraduate Innovative Education base.

\section{Practice time requirement}

Of full-time engineering master of management practice time clearly defined in 26 institutions ,19 colleges and universities require full-time graduate practice time at least 6 months, accounted for $73.5 \% .5$ required colleges in 12 months. 2 requires only 3,4 months, compared very relaxed.

However, Practice time requirements for part-time Masters, access to relevant data from 42 institutions, 34 of them require at least 6 months, accounting for $81 \%$ of 42 institutions. A few schools require only 3 or 4 months, and 4 schools require 12 months, or even 18 months (Shanghai University of Finance and Economics). But they are just a case in point. Therefore, there is not a systematic standard for the requirements of fulltime and part-time Engineering Management Masters in our country, and there is also no obvious distinction between the two types of masters in the setting of practice time.

\section{E. Thesis quality management}

Quality management can be divided into the words, the writing time and whether the schools do the important work of the three (opening comments, format specification, the review of the blind trial). In our country, problems such as lack of 
technical application and feasibility of engineering practice have appeared in the past because of the theoretical control of the supervisor, the fact that the selected topic can not really reflect the characteristics of the project [4]. Therefore, to ensure the opening appraisal of master of engineering management orderly, become the basis for paper quality. Similarly, for the students who have been working for several years, the role of format norms can not be ignored. The effect of "blind trial" has been proved by the research of Zhang Xiaoyan and others. It can improve the quality of the paper. Therefore, we have statistics on these three items.

\section{1) Survey of full-time Master of engineering management}

The results show that writing time and number of words required in 17,14 is more than 12 months, two of them even 18 months and 24 months; the remaining three is located between 6-10 months. Very few schools have requirements on time limit.

14 schools have different requirements for word count, More than half ( 9 schools) require 30 thousand words, 25 thousand words and 40 thousand words, which belong to very few (each has one). There are also schools with limited number of words, such as the Shenyang Construction University, which requires 40-50 thousand words.

In the three aspects of the work, 37 sets of data are included, 25 schools also have the title appraisal and provide the format specification, 12 schools have all three aspects. That is, one third schools do three jobs at the same time, and two third schools have yet to do anonymous Reviews.

\section{2) Master of non full-time engineering management}

Of the 27 sets of data, 23 schools require paper writing for 12 months or more. Very few require only 3-9 months or 18 months (1 school).

There are 29 institutions with papers and word requirements. 10 of them require at least 30 thousand words; 2 are more stringent, in 40 thousand words; and 7 are more relaxed, 20 thousand words or 25 thousand words. 60 sets of data, at the same time for the title and format requirements, but not blind trial requirements are $42 ; 11$ colleges have three requirements; that is, the 1 trial of anonymity. That is, the $70 \%$ universities completed two title appraisal and the format specification, but slightly less than one third in three work is done [7].

\section{CONCLUSION AND DISCUSSION}

The results of the survey show that in China colleges to recruit the full-time Master of Engineering Management are more than half to recruit the part-time Master of Engineering Management. It indicates that the master of engineering management is inclined to be part-time in training mode, which is closely related to the requirements of enrollment. At the same time, to a certain extent, the project management personnel more choose to non full-time way (not off duty) for further study.

In the training mode, the practical talents are emphasized in the objective and specific purpose of training the master of engineering management, and the requirements of the students' practice time are also required, and the value of the enterprise tutor can not be ignored. But in fact, only 12 schools in the survey sample clearly defined the system of dual Mentors (corporate mentors and academic mentors). 48 of them are enrolled in full-time engineering management masters, but only one fourth. If coupled with the number of non full time institutions, the proportion will be even smaller. It is also a problem in the training of domestic Master of engineering management identified in this survey.

Most schools require students to practice for more than half a year, but the proportion of non full-time engineering management candidates to choose the practice time is higher (81\%), while full-time only $73.5 \%$.Two masters have the opportunity to do only 3 or 4 months of internship, it is standard. Only a small number of schools require students to practice for more than one year. However, there is only one school (Shanghai University of Finance Economics) in the off campus for 18 months. But there is no systematic standard for the practice time of full-time and part-time Engineering Management Masters in our country. Moreover, there is no significant difference between the two types of master's in practice time setting.

Similarly, full-time and part-time master of Engineering Management also have a similar, less discriminative problem in thesis quality management. For example, schools that require 12 months of paper writing time are over $80 \%$ in two categories of master's degree programs. There is no obvious difference in writing time or word requirement. But these aspects should have a big difference, in order to reflect the fulltime and part-time training methods for students of different requirements.

The quality management of the paper has a common character, that is, one third institutions at the same time do three jobs, not anonymous accreditation institutions, but also two third. This form will have a bad influence on the quality of full-time and part-time project management master's thesis, and it also shows that the quality evaluation system of Engineering Master's degree thesis is not complete at home.

In summary, in order to ensure the training quality of master of Engineering Management, our country should improve the quality assurance system, the key point of the education process, the quality control, the construction of the relevant environmental protection system, and the participation of the professional circles. This template, modified in MS Word 2007 and saved as a "Word 97-2003 Document" for the PC, provides authors with most of the formatting specifications needed for preparing electronic versions of their papers. All standard paper components have been specified for three reasons: (1) ease of use when formatting individual papers, (2) automatic compliance to electronic requirements that facilitate the concurrent or later production of electronic products, and (3) conformity of style throughout a conference proceedings. Margins, column widths, line spacing, and type styles are built-in; examples of the type styles are provided throughout this document and are identified in italic type, within parentheses, following the example. Some components, such as multi-leveled equations, graphics, and tables are not prescribed, although the various table text styles are provided. 
The formatter will need to create these components, incorporating the applicable criteria that follow.

\section{REFERENCES}

[1] Liu Hongyong, Chen Pingping, and Zheng Junwei,"Analysis of training path of master degree of engineering management major in China" in Industry and information education, vol. 8,2014, pp.5-10+25.

[2] The project management master degree graduate student guidance training program (Trial Implementation) .Available online: http://www.mem.edu.cn/publish/mem/58/2011/20111116093916422139 189/20111116093916422139189_html.

[3] Zhao Chuanping,"Study on the quality standard of master of engineering management". Thesis\&dissertation. Zhejiang University, 2010.
[4] Zhang Xiaoyan, Song Maoqiang,"Process management and quality control of full time master's degree thesis" in Graduate education research, vol.3, 2011, pp. 69-72.

[5] Luo Changfu.Study on Quality Management for Graduate Education Service.Ph.D,Chinese Academy of Agricultural Science,Beijing,2006.

[6] Xu Changqing.Evaluation Report on the Development of Postgraduate Education Quality in Professional Degree: A Case Study of Research Universities in South China.Modern University Education 2012,(03),93100.(In Chinese)

[7] Zhou Ling.Research on the quality assurance system of graduate degree thesis in order to improve the quality of postgraduate training. Changchun Inst. Tech. ( Soc. Sci. Edi. ) 2015, 16,4,DOI: 10.3969 /j.issn.1009-8976.2015.04. 028. 